\title{
13
}

\section{Dual-Earner Family Policies at Work for Single-Parent Families}

\author{
Laurie C. Maldonado and Rense Nieuwenhuis
}

Family dynamics are changing and single-parent families are becoming more common across countries. In their flagship report "Progress of the World's Women, 2019-2020," UN Women (2019) demonstrated that, contrary to popular belief, couples with children do not constitute a majority of all families, but rather there are many different types of families (also see Chapter 5 by Razavi and Chapter 9 by Adema, Clarke, and Thévenon, both in this volume). Single parenthood is considered a "new social risk" in poverty and inequality (Bonoli, 2013). Therefore, policy makers and legislators have designed targeted policy specifically for single parents, such as targeted child benefits to single parents. In addition, legislation and social policy have been designed and implemented specifically for single parents, such as child support (as analyzed in Chapter 12 by Skinner and Hakovirta in this volume) and family law such as child custody and shared residence. This chapter takes a different approach, based on the universalist argument that without adequate social protection that benefits all families, those families that are more vulnerable are often hit the hardest. We focus on family policies, and

L. C. Maldonado $(\bowtie)$

Molloy College, Rockville Centre, NY, USA

e-mail: 1maldonado@molloy.edu

R. Nieuwenhuis

Swedish Institute for Social Research (SOFI), Stockholm University, Stockholm, Sweden

e-mail: Rense.nieuwenhuis@sofi.su.se 
specifically we examine whether and to what extent single parents benefit from the same family policies that are available to all families with children.

Based on the extant literature on single parents and family policies, there seems to be a strong case that family policy does reduce poverty among all families with children. In fact, some literature even suggests that single parents benefit more from universal family policies than couples with children. This position can also be found in our own work (Maldonado \& Nieuwenhuis, 2015; Nieuwenhuis \& Maldonado, 2018b), but the claim is far reaching and requires further review. This chapter sets out to examine how family policies differently affect the poverty rate of single-parent families versus couples with children and also probes whether or not there is a premium-or penalty-for single parents. Following Daly (Chapter 2 in this volume), we focus on child income support (with an emphasis on family benefits), early childhood education and care (ECEC), and parental leave. We review the literature on the question of whether these policies benefit single-parent families more. In addition, we examine a number of comparative family policy data infrastructures to empirically examine the question of whether family policies provide additional benefits to single-parent families.

The remainder of this chapter is organized in three parts. First, we introduce the rise of single parenthood and aspects of their well-being such as their employment and their elevated poverty risk. It provides a theoretical framework to explain challenges associated with single parenthood. The next section provides a literature review on family policy outcomes for single parents and parents in couples. This is followed by an empirical illustration of what can be learned regarding the question to what extent single parents and two-parent families benefit from family policies. To conclude, we examine how to improve the data infrastructures and research to deepen our understanding of the role of family policy in improving the lives of single parents and their children.

\section{Single Parents in a Triple Bind}

Single parenthood has become increasingly common, but varies substantially across OECD countries. The share of households with children that are headed by a single parent (as a percentage of all households with dependent children) ranges from around 10\% (e.g., in Italy, Poland, or Slovenia) to around 25\% (e.g., in the United States, Sweden, and Ireland) (Nieuwenhuis \& Maldonado, 2018b). Gender inequality is a major concern, as the majority of single-parent families are headed by women. At the same time, there are 
shifting demographics and a small and slightly growing percentage of singleparent families that are headed by fathers. In fact, fathers are becoming more involved in the care for their children (even separated fathers), especially in the Nordic countries (Nieuwenhuis, 2020). Single parents face higher risks of poverty compared to couples with children, and this is more pronounced in some countries (Nieuwenhuis \& Maldonado, 2018b). The challenges faced by single parents can be explained by the triple bind framework.

Single-parent families risk being caught in a triple bind of inadequate resources, employment, and policy (Nieuwenhuis \& Maldonado, 2018b). With respect to their resources, single parents are likely to have a low level of education compared to parents in a couple (McLanahan, 2004). This pattern of an "educational gradient" was found across a number of social-democratic, liberal, and continental welfare regimes (but not in Southern Europe), yet was found to hardly be the "smoking gun" (Härkönen, 2018, p. 43) in explaining single parents' elevated poverty risks. Instead, with only one earner and caregiver in the household, single parents are without a potential second earner to fall back on during difficult economic times and without a second caregiver to help combine work and family responsibilities. The majority of single parents work; however, many are employed in low-quality jobs. Jobs that are often low wage, without protection, and without adequate workfamily supports. Working single parents are more likely to experience in-work poverty compared to parents in couples (Nieuwenhuis \& Maldonado, 2018a) and experience worse work-life balance (Esser \& Olsen, 2018). The third bind pertains to inadequate or missing policy. For instance, many countries have policies that support employment as a means to reduce poverty, but if such demands are not met by the support to combine work and family responsibilities, it may be particularly difficult for single parents to meet such demands. Taken together, the triple bind makes it difficult for single parents to work and care for their families. Inadequate resources and employment, combined with no social safety net and an ineffective family policy, can leave far too many single-parent families in poverty.

The triple bind of single-parent families provides some insights for family policy. On one hand, most aspects of the triple bind are not unique to single parents. Couples with children, too, can experience in-work poverty, particularly if they have not obtained a high level of education. In addition, they can experience difficulties in combining work and family, and of course, caregiving responsibilities are not equally shared among couples (even in comparatively gender-equal societies as Sweden; Evertsson \& Nermo, 2007). As such, it may be expected that single parents and couples with children alike benefit from income supports to children, as well as ECEC and 
parental leave to combine work and family. On the other hand, single parents are more likely to face many aspects of the triple bind compared to couples with children. Although parents in couples face similar work-family conflicts, single parents have far greater challenges with less income and less ability to share care work. This increased need for child income support and workfamily reconciliation policies may also increase the benefit they gain from such family policies.

\section{Literature Review}

\section{Child Income Support: Family Benefits}

Child income supports, such as family benefits, have proven to be a key instrument against poverty among families with children. Family benefits, a type of cash transfer that offsets the cost of raising children, are particularly effective in reducing poverty for single-parent and two-parent families (Bradshaw \& Finch, 2002; Bradshaw, Keung, \& Czhen, 2018; Chzhen \& Bradshaw, 2012; Gornick \& Jäntti, 2012; Maldonado \& Nieuwenhuis, 2015; Morissens, 2018). Bradshaw and Finch (2002) studied child benefit packages across countries using model families to assess the generosity of child benefit levels. They found that countries with more generous child benefit packages have lower child poverty rates. Chzhen and Bradshaw (2012) later examined both poverty and material deprivation among children in singleparent families. They found that poverty is lower in countries with higher transfers, whereas material deprivation is more related to a country's standard of living. Gornick and Jäntti (2012) report similar findings: that redistribution significantly reduced child poverty. Bradshaw et al. (2018) showed that the amount of received, as well as other benefits, is a significant portion of single-parent families' household disposable income.

Some have raised concerns about moral hazard regarding income benefits and family formation. For instance, income benefits may encourage single parenthood. However, this argument was strongly countered by Brady, Finnigan, and Hübgen (2017). In their framework that distinguishes between the prevalence and penalties associated with risk factors for poverty, they found that higher benefit transfers reduce the poverty penalty associated with single motherhood but that this did not increase their prevalence. More generally, the literature shows a limited impact of child benefits on fertilityas detailed in Chapter 9 by Adema, Clarke, and Thévenon in this volume. 
In other words, benefit transfers do not entice people to become a single parent but do reduce their poverty.

In addition, it is important to examine which benefits are targeted toward low-income families. Research has investigated the effectiveness of benefits targeted specifically to those who need it the most vis-à-vis benefits that are designed for all families (Kenworthy, 2011; Korpi \& Palme, 1998; Marchal \& Van Lancker, 2019; Marx, Salanauskaite, \& Verbist, 2016; Skocpol, 1991; Van Lancker, Ghysels, \& Cantillon, 2015; Van Lancker \& Van Mechelen, 2015; Van Oorschot \& Roosma, 2017). In their seminal study, Korpi and Palme (1998) showed that universal transfers were more effective to reduce poverty overall than transfers targeted specifically at the poor. They addressed this "paradox of redistribution" by arguing that heavily targeted benefits lose the partisan support of middle-class and higher income voters, and therefore, such benefits are at risk of being cut. Brady and Burroway (2012) also found that universal transfers have been more effective in reducing poverty than transfers targeting single-parent families.

Other researchers have shown that the "paradox of redistribution" is less of a concern. Marx et al. (2016) found that current minimum income protection schemes alone are insufficient to reduce poverty. Instead, poverty reduction may benefit from a combination of both universal and targeted benefits. Van Lancker et al. (2015) found that targeting child benefits for single-parent families is an effective way to reduce poverty, as long as adequate overall levels of redistribution are maintained. Morissens (2018) found that targeted benefits and universal benefits are both indispensable in reducing poverty among both working single parents and single parents who are out of work.

\section{Early Childhood Education and Care (ECEC)}

Public services for ECEC are arguably among the most important to support working parents (Olivetti \& Petrongolo, 2017) as well as beneficial to children's well-being and development (Gambaro, Stewart, \& Waldfogel, 2015). ECEC is most effective when it is available, affordable, and of adequate quality (ibid., also see Chapter 8 by Vandenbroeck and Chapter 24 Sirén, Doctrinal, Van Lancker, and Nieuwenhuis, both in this volume). Family care needs can form barriers to paid work and be nearly impossible to reconcile with work requirements. One alternative is to rely on informal care arrangements, but those do not necessarily offer the stability necessary to maintain employment (Van Lancker \& Horemans, 2017). 
Public childcare is essential to single mothers' employment. Bainbridge, Meyers, and Waldfogel's (2003) US-based study found that childcare subsidies for working single mothers stimulated employment more so than for single mothers on welfare. They also found that family tax benefits to support childcare explained a larger share of single mothers' employment. They underlined the importance of examining specific aspects of childcare policy. Berger and Black (1992) also discussed childcare policy provisions and the need for high-quality childcare. In their study of Finland, Netherlands, and the UK, Moilanen, May, and Räikkönen (2016) found that working single mothers experience more childcare-related challenges, particularly when working nonstandard hours. In a large comparative study, Van Lancker (2018) found across European countries that single parents who had used ECEC services when their children were young were indeed more likely to be employed later in life.

The benefits of ECEC extend beyond increasing the likelihood that single parents are employed; they also improve employment conditions or improve work-life balance among those who are employed. Nieuwenhuis, Tøge, and Palme (2018) showed that ECEC services were associated with more single parents in employment but also that this employment was associated with a larger health benefit in societies with more extensive ECEC provisions. At the same time, single parents who were not employed experienced poorer health (but less so in countries with higher levels of child income support). More generally, Millar and Rowlingson (2001) reported that single parents do well in jobs that are not only well paid but also well supported (also see Rowlingson \& McKay, 2002). Esser and Olsen (2018) found that working single parents experience less work-life balance but also that their work-life balance is supported in countries with dual-earner, dual-carer family policies (such as ECEC, but also paid parental leave).

\section{Parental Leave}

Parental leave policies ensure that parents can take leave from their employment around the time of the birth of their child(ren) and during the early years of their childhood, while guaranteeing that parents can return to their job after the leave and still receive some level of continued wage payment or wage replacement (Gornick \& Meyers, 2003). As such, it is a policy that inherently promotes and protects parents' attachment to the labor market and can be an effective strategy to reduce poverty. In a comparative study of 18 OECD countries, leave was found to reduce poverty by facilitating employment-more effectively so among single parents than two-parent families 
(Maldonado \& Nieuwenhuis, 2015)—so that a single parent may take time off to care for a sick child and return to work without fear of losing the job. However, parental leave had to be matched with some level of wage replacement, as unpaid parental leave did not reduce poverty. Moreover, paid parental leave was found not only to elevate single parents out of poverty but also to increase the likelihood of achieving a middle-class income (Byun, 2018).

As is the case with many family policies, the design of the parental leave policy matters to determine its effectiveness and possible trade-offs. These tradeoffs are discussed in great detail in Chapter 11 by Hook and $\mathrm{Li}$ in this volume, so here it suffices to focus on one such tradeoff particular to single parents. It has often been documented that overly long periods of parental leave are a mechanism of exclusion of women from the labor market (Nieuwenhuis, Need, \& Van der Kolk, 2017; Pettit \& Hook, 2009). Misra, Moller, and Budig (2007) showed that a number of different family policies reduced poverty among single-parent families, although they cautioned that overly lengthy parental leave may have unintended consequences for single mothers and the labor market. Van Lancker (2018) showed that leave was associated with a larger probability of single parents being employed in countries with moderate levels of leave. Yet, in countries with very long durations of leave, having used parental leave was associated with a lower probability of being employed. Van Lancker thus confirmed that many of the tradeoffs associated with overly long parental leave also apply to single mothers.

A life-course perspective helps understand how paid leave policies can be effective for single parents later in life, even when they are separated from their partner (becoming a single parent) years after they last qualified for taking parental leave. Bernardi and Mortelmans (2018) described the trajectories of single parenthood and their poverty, work, health, migration, and how these vary across the life course and are diverse across families and countries. Zagel (2014) detailed the various employment trajectories of single mothers. Single mothers' employment state includes full time, employmentoriented, part time, part time return, gradual return, causally employed, and inactive. Zagel (2014) explained that single parents enter and leave single parenthood at very different points in time. There are multiple pathways to being a single parent, such as divorce, separation, death of a partner, and choice such as birth/adoption of a child by a single parent. In sum, the parental leave used by parents in couples, thus promoting gender equality in terms of labor force attachment and the accumulation of work experiences, resonates later in the life course-including among those who have become a single parent. 
Recently, there has been greater attention directed to fathers' involvement in care work. Paid paternity leave is associated with higher participation of fathers in childcare and better school performance among children (Nepomnyaschy \& Waldfogel, 2007). The positive effect of paternal leave is also associated with greater participation in care for their child(ren) later in life (Duvander \& Jans, 2009). In Sweden, parental leave rights are individualized and are mostly non-transferable, which encourages fathers to take substantial amounts of leave. As parents can use their 8 months of (paid) parental leave rights until their child reaches 8 years of age, even fathers who are separated from the mother of their child(ren) can continue to take leave (Duvander \& Korsell, 2018). Fransson, Brolin Lafman, Ostberg, Bergstrom, and Olsen (2018) showed that in Sweden, it is increasingly common that children from separated parents live about equal amounts of time with both parents. Such forms of shared residence currently are a hot topic of ongoing investigation, but studies across a variety of contexts seem to indicate that shared residence is beneficial to the well-being of children (Baude, Pearson, \& Drapeau, 2016; Nielsen, 2014).

\section{Empirical Analysis}

Following the literature review above, this section utilizes various data infrastructures to illustrate the extent to which family policies benefit single-parent families more, less, or to same extent as two-parent families. Again, we focus on child income support (with a focus on family benefits), ECEC, and parental leave policies.

\section{Child Income Support: Family Benefits}

When it comes to analyzing how family policies differently benefit single parents versus couples with children, family benefits are probably the best covered in common data infrastructures. We highlight the Luxembourg Income Study (LIS) database to illustrate an empirical example of, and data from the Social Policy Indicator Database (SPIN) on child benefits and outof-work benefits from a social rights perspective. It should be noted that particularly with respect to family benefits, a wide range of other data infrastructures are available, such as EUROMOD (Sutherland \& Figari, 2013)-a tax-benefit microsimulation model for the European Union, that comes with the Hypothetical Household Tool (HHoT) for model household type based 
analyses of social rights and the CSB Minimum Income Protection Indicators Database (Van Mechelen, Marchal, Goedemé, Marx, \& Cantillon, 2011) that includes data on minimum income protection provisions in Europe and the United States over two decades.

The LIS database harmonizes pre-existing micro-data to a common template in order to maximize comparability across countries, providing a wide range of variables on persons and households. These data focus on various sources of income (and taxes paid), including different components pertaining to redistributive social policies such as family benefits. Other sets of variables pertain to demographics, employment, and household composition; the latter makes it possible to use LIS to examine the impacts of family benefits on single-parent and couple-parent families.

In a common type of policy analysis with LIS, researchers aim to quantify the redistributive impacts of welfare state redistribution (whole or part of a specific policy) on a measure of income, inequality, or poverty (Chzhen \& Bradshaw, 2012; Gornick \& Jäntti, 2012; Gornick \& Smeeding, 2018). Here, we examine the impacts of family benefits on single parents and couples with children who are at risk of poverty. To this end, poverty rates are calculated based on two income concepts: first, based on disposable household income (after all benefits are received and taxes are paid); and second, based on disposable household income, minus the amount of family benefits that the family has received. This latter poverty rate represents how high poverty would have been without family benefits. The difference between the two poverty rates can be attributed to family benefits. This type of decomposition is not without limitations, as it is assumed that people do not change their behavior in the absence of certain benefits, and when the analyses are performed for multiple benefits, it remains unclear which of the benefits lifted the household out of poverty (Nelson, 2004). Nonetheless, the type of decomposition as described above indicates the capacity of family benefits to lift different families out of poverty.

An example of this type of decomposition analysis is presented in Fig. 13.1, for single-parent families and couples with children separately. The green bars indicate the at-risk-of-poverty rates based on disposable household income, and the orange bars indicate how high poverty would have been without family benefits. The length of the orange bar can be interpreted as the redistributive impact of family benefits on poverty.

A few findings stand out in Fig. 13.1. First, single parents face poverty risks that are substantially higher compared to couples with children, with considerable differences among countries. For instance, single parents' poverty is lower in the Nordic countries than in Canada, Luxembourg, or the United 


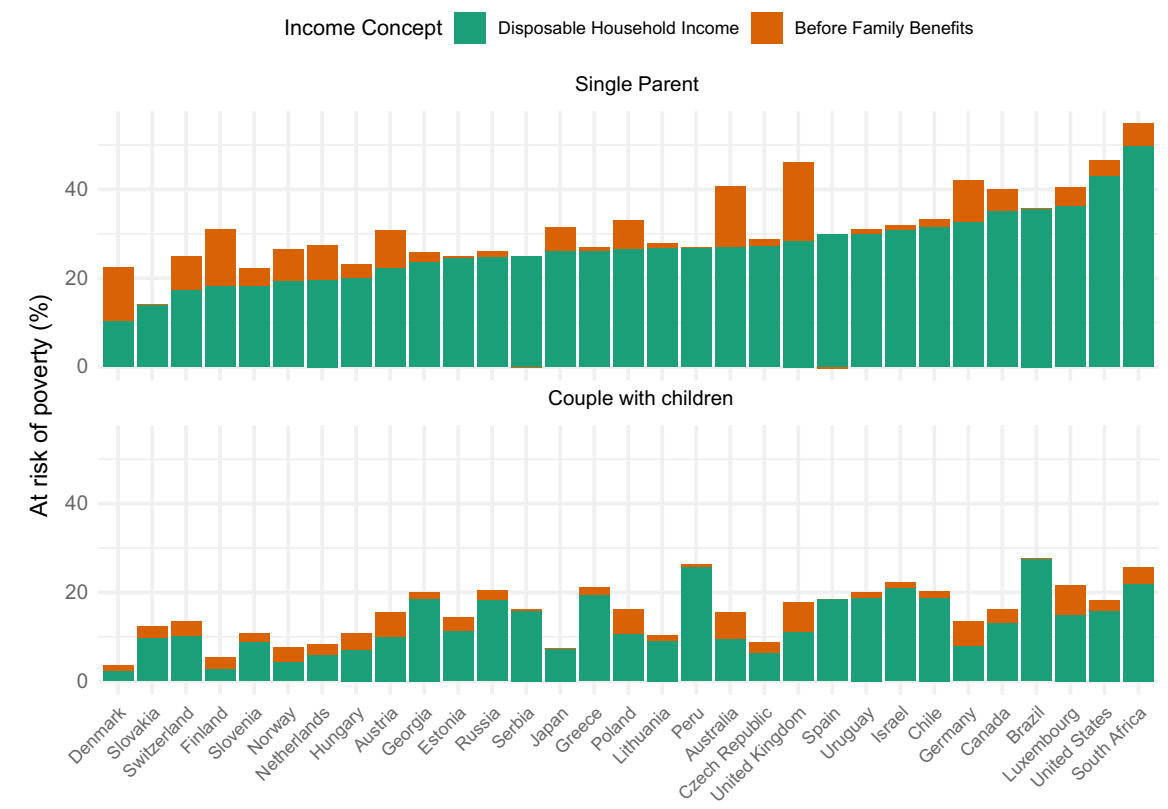

Fig. 13.1 Family benefits are associated with lower poverty for single-parent and coupled-parent families (Source LIS data)

States. Second, without family benefits, poverty among single parents would be substantially higher in most countries. This can be seen by the length of the orange sections of bars. Third, again in most countries, family benefits are associated with larger poverty reductions among single parents than among couples with children (indicated by the larger orange bars among the former).

At first glance, Fig. 13.1 suggests that family benefits reduce poverty risks for all families and more strongly among single parents. However, these analyses are in fact not informative about why this is the case. It can, for instance, not be distinguished whether single parents benefit more because they had incomes closer to the poverty line (and therefore require smaller family benefit amounts to be lifted out of poverty) or because they receive higher amounts. Therefore, Fig. 13.2 explores this poverty threshold inquiry further.

Figure 13.2 shows for poor families just how far their income falls short of the poverty line. For the calculation of poverty gaps, we used the poverty line and household income before family benefits were included. The poverty gaps are represented as a percentage of national poverty. The results suggest that there is no consistent pattern among countries that show poor single parents are closer to the poverty line than poor parents in couples. In fact, in more than half the countries, poor single parents are further behind the poverty line compared to poor couples with children. 


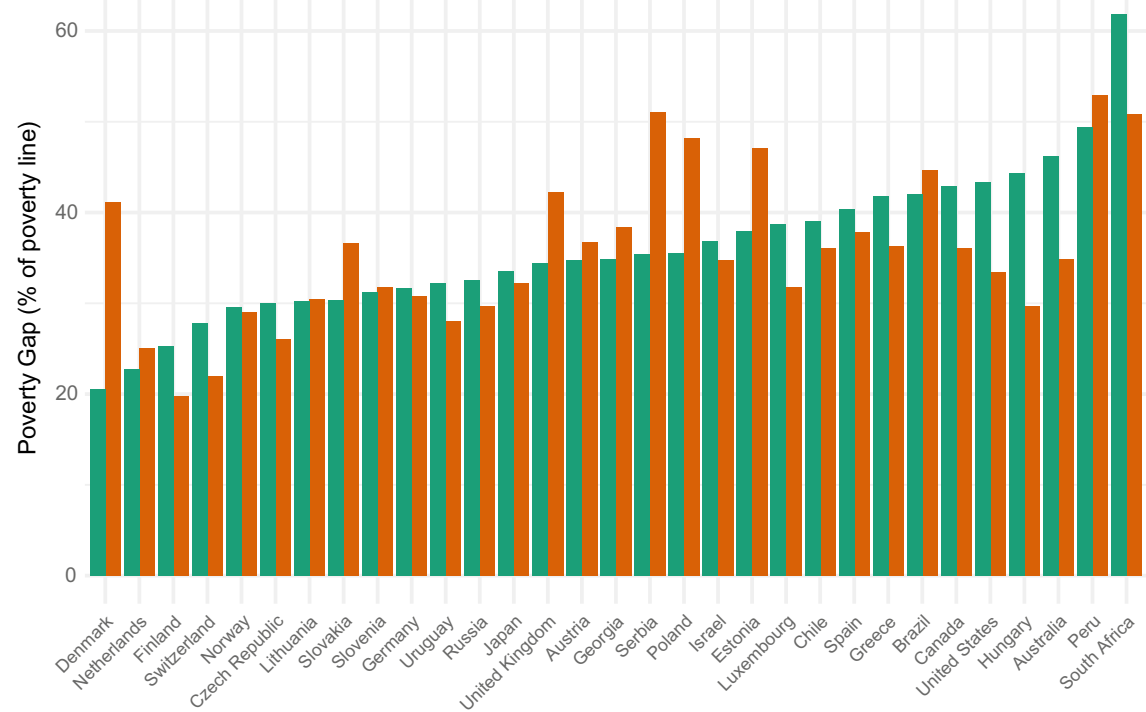

Fig. 13.2 Poverty gaps among poor single parents are not systematically larger than poverty gaps among poor couples with children (Source LIS Data)

For instance, in Denmark, the income of single parents in poverty is, on average, $20 \%$ below the Danish poverty line, whereas among couples with children, it is about $40 \%$ below the poverty line. It is important to point out that single parents in Denmark had a greater likelihood to be poor than couples with children (Fig. 13.1), but this indicator (Fig. 13.2) shows that among the poor, couples with children in Denmark tend to be worse off. Therefore, this evidence shows it is not the case that single parents are closer to the poverty line but instead shows why family benefits are associated with larger poverty reductions among single parents.

So far, Figs. 12.1 and 12.2 build a strong case that higher family benefits reduce poverty. However, these illustrations do not fully capture whether or not higher benefits reduce poverty more among single-parent families. Therefore, in Fig. 13.3, we present the association between how family benefits are and their poverty reduction about single parents and couples with children.

In Fig. 13.3, countries are positioned on the $\mathrm{x}$-axis according to the amount of family benefits that households have received (equivalized for household size). For instance, in Australia and the United Kingdom, single parents (18-22\% of the poverty line) received substantially more than couples with children (around 10\%), whereas in Estonia and Luxembourg, couples with children received higher family benefits than single parents. The y-axis 


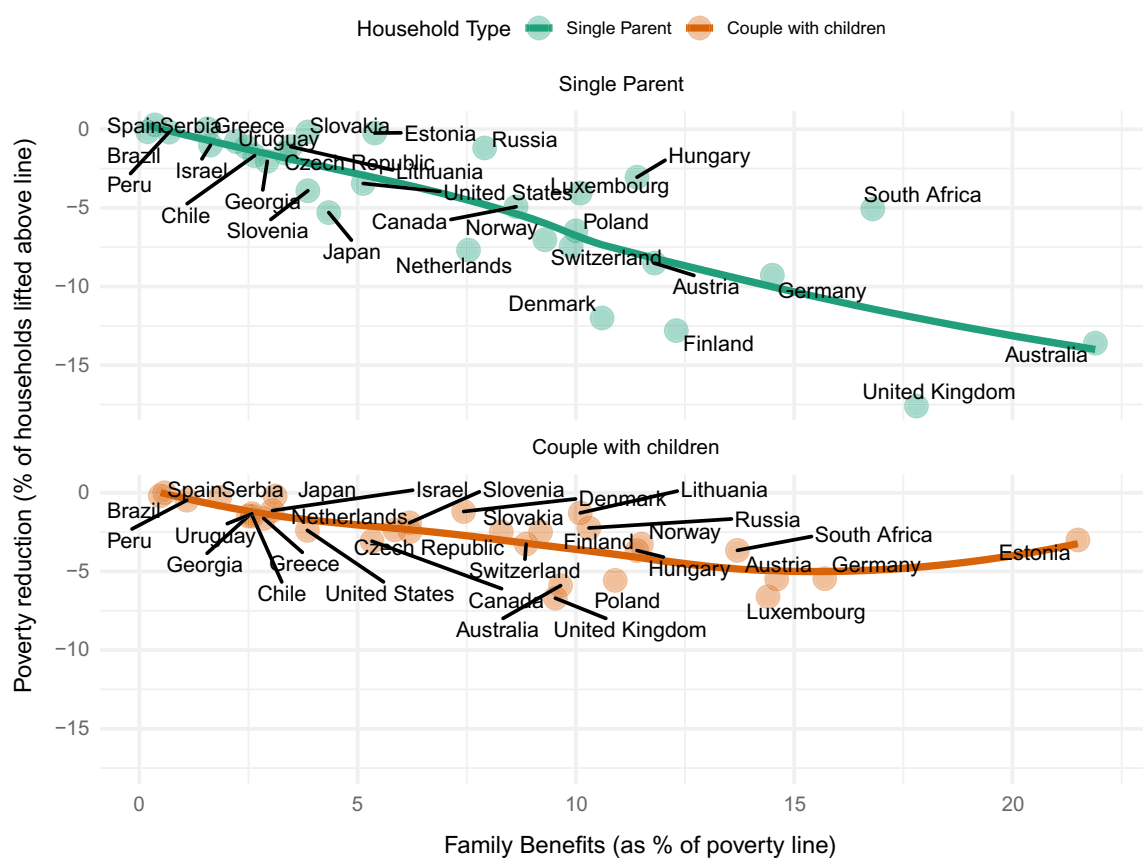

Fig. 13.3 Higher family benefits reduce poverty more, in particular, among singleparent families (Source LIS Data)

shows the poverty reduction associated with family benefits, which corresponds to the length of the orange bars in Fig. 13.1. Higher family benefits tend to reduce poverty to a larger extent, and the association between the levels of family benefits and the degree of poverty reduction is stronger among single parents than among couples with children. In other words, a given level of family benefits lifts more single-parent families out of poverty than couples with children. There are several explanations for this finding. First and foremost, single parents have higher poverty rates, which mean that a larger proportion of this group can be lifted out of poverty. A second plausible explanation is the degree of targeting. High degrees of targeting may be associated with lower levels of benefits overall (Korpi \& Palme, 1998), as a given level of family benefits targeting may be associated with greater poverty reductions (Van Lancker et al., 2015). In an analysis of the institutional design of family benefits (Marchal \& Van Lancker, 2019), it was found that many countries (e.g., the United Kingdom and the United States) target family benefits heavily toward lower incomes, although there was no clear pattern that this degree of targeting is stronger among single parents than among couples with children. However, as single parents are more likely to have a low income and be in poverty (Fig. 13.1), the degree of low-income targeting 
contributes to the explanation of why more single parents than couples with children are lifted out of poverty at a given level of family benefits.

Next, we examine family benefits and unemployment insurance using model family types (for a discussion of the use of model family types as compared to observational data see Chapter 24 by Sirén, Doctrinal, Nieuwenhuis, and Van Lancker, in this volume). In many countries, couples with children receive higher benefits than single parents (cf. Fig. 13.3). However, it cannot be inferred that the family benefit policies were designed to award couples with children higher family benefits. Take for instance, the levels of family benefits that are dependent on the number of children in families. So even if the policy is designed to award a universal amount of family benefits per child-irrespective of income and family composition-couples might receive more benefits if they have more children. Such differences in socioeconomic and demographic makeup of families (often referred to as "policy demand") obfuscate analyses of micro-level data that seek to infer what the policies intend to provide to families (often referred to as "policy supply"). ${ }^{1}$ A commonly applied technique to isolate the design to better understand intentions of policy is to analyze model families (Bradshaw, Ditch, Holmes, \& Whiteford, 1993), which is a set of narrowly defined family compositions, for the social policy rights are calculated across contexts. As the families are kept identical across contexts, differences in which family benefits are entitled to can only be attributed to differences in how the policies are implemented, not to differences in the socio-economic composition (the "policy demand") of these families.

The SPIN database is a long-standing data infrastructure on policy indicators (Ferrarini, Nelson, Korpi, \& Palme, 2013). With a focus on social security, SPIN is comprised of several databases, including the Out-ofWork Benefits Dataset, the Child Benefit Dataset, the Parental Leave Benefit Dataset, the Social Assistance and Minimum Income Protection Interim Dataset, the Social Citizenship Indicator Program, and the Social Insurance Entitlements Dataset. These databases are based on the social rights perspective (cf. Marshall, 1950), using the method of model families. As described above, such indicators capture what policies intend to do (e.g., what rights citizens can expect) rather than what citizens do with these policies (e.g., take up). As such, these indicators can be used to analyze changing welfare states as well as different welfare state outcomes across countries or over time. Many of the databases in SPIN have model families representing both couples with children as well as single-parent families, with the exception of the Child

\footnotetext{
${ }^{1}$ For more on this issue, see Chapter 24 by Doctrinal, Sirén, Nieuwenhuis, and Van Lancker, in this volume, on childcare policy indicators.
} 
Benefit database (for which the source data did not provide information on single parents). Nonetheless, indicators on income support such as child and family benefits are included in several other databases.

In Fig. 13.4, we present results from the Out of Work Benefits database (Doctrinal, Nelson, \& Sirén, 2015). The model families are assumed to have worked but then became unemployed and therefore qualify for insurancebased unemployment benefits. In insurance-based benefits no differences in benefit levels are to be expected between family forms-in contrast to means-tested, social assistance-based benefits. Yet, the income situation of different family types may differ in times of unemployment, for instance, due to additional transfer such as from family benefits. Both the single parents and the couples are assumed to have two dependent children. The benefits these families receive are calculated at different wage levels (referring to their employment before becoming involuntarily unemployed), ranging from 50 to $200 \%$ of average wage. The indicators in Fig. 13.4 represent the average of these calculations at different wage levels. The green bars represent the level of

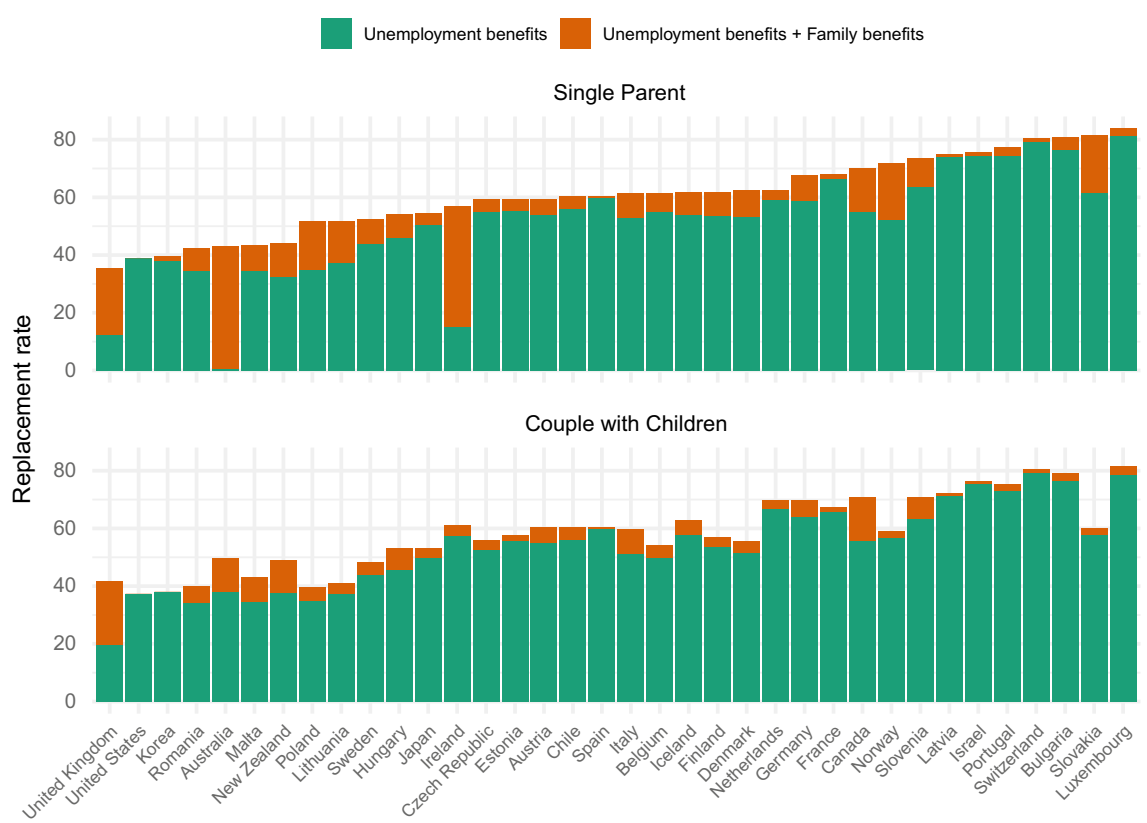

Fig. 13.4 Family benefits remain an important source of income, even after accounting for unemployment benefits, more so for single-parent families (Source Out of Work Benefits Database) 
unemployment benefits these families receive, and the orange bars represent the unemployment benefits topped with family benefits. ${ }^{2}$

In comparing single parents to couples with children, it is observed that in most countries, their income position is similar to that of couples with children but that their income relies to a larger extent on family benefits. This is particularly the case in Australia, Ireland, and the United Kingdom. It should also be noted that for these model families who have been working full-time but lost their jobs, insurance-based unemployment benefits are a more important part of their income. Nonetheless, family benefits represent an important addition to their income to provide financial support for their families. It should also be noted that in contemporary dual-earner societies, many couples (with and without children) have two incomes. An income replacement of substantially less than $100 \%$ during unemployment is a harder burden for a single parent without a second earner. This has been identified as a major risk factor for single-parent poverty (Alm, Nelson, \& Nieuwenhuis, 2020).

Figures 13.1 through 13.3 support that higher amounts of family benefits reduce poverty for families with children. Figure 13.3 further shows that single parents have a steeper slope and perhaps benefit more. Figure 13.4 accounts for socio-demographic characteristics through the use of model family types and examines unemployment benefits topped up with family benefits. The findings suggest that family benefits are an important source of income, but that in particular for single parents, family benefits represent a substantial top-up in a large number of countries.

\section{Early Childhood Education and Care (ECEC)}

ECEC is an important policy measure for the work-family reconciliation of all families and is crucially important for single-parent families. Here, we focus on an indicator of ECEC affordability, for both single parents and couples with children. These data, presented in Fig. 13.5, are from the OECD Family Database, ${ }^{3}$ based on calculations using the OECD Tax and Benefit Models $2015,{ }^{4}$ by model household types. This ensures comparability across contexts, and this particular example allows for an important comparison of

\footnotetext{
${ }^{2}$ It is not possible to disentangle these amounts in all countries, as the level of net benefits received from either unemployment or family benefits can be adjusted to what other income (from benefits or otherwise) these families receive. Nonetheless, the indicators represent the share of family benefits that make up their income.

3 www.oecd.org/els/family/database.htm.

${ }^{4}$ http://www.oecd.org/social/benefits-and-wages/.
} 


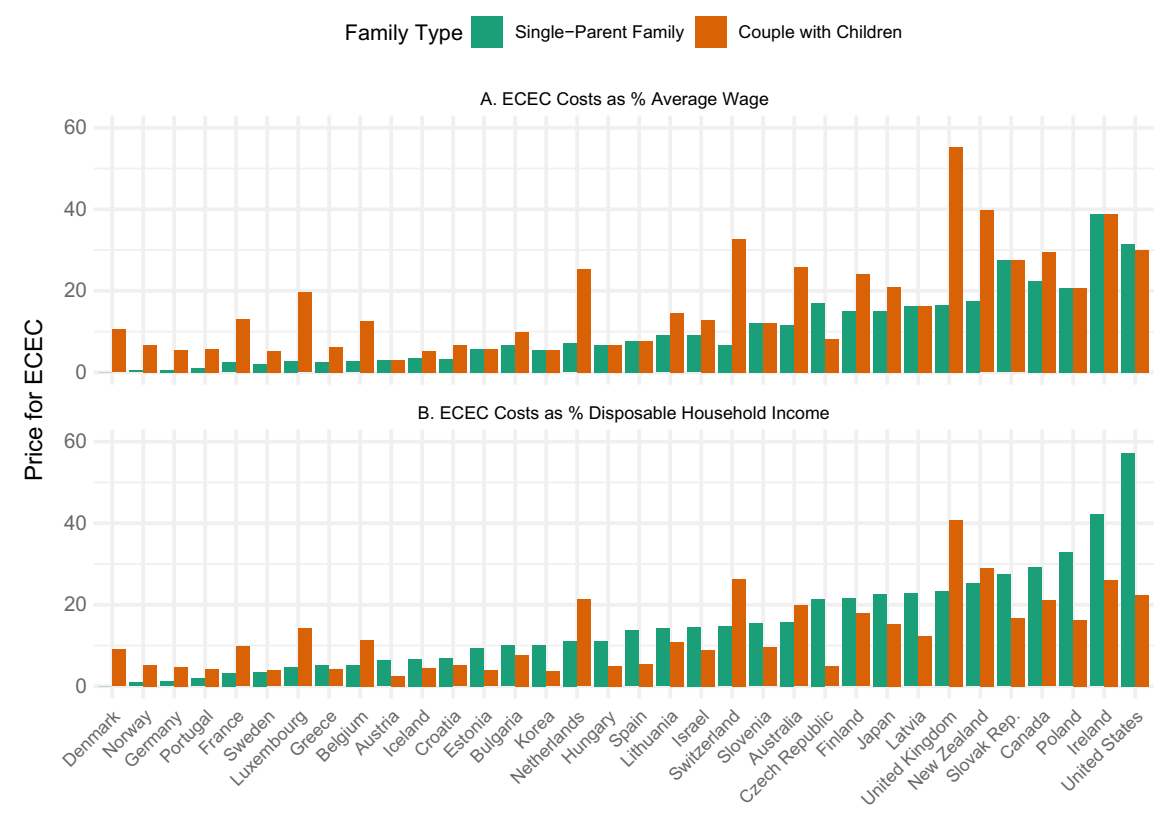

Fig. 13.5 Single parents do less in ECEC than couples with children; however, single parents pay a larger share of their household income (Source OECD Family database)

single-parent families and couples with children. The single parent is assumed to work full-time at the national average wage, whereas the couple consists of a full-time worker and one working at least $67 \%$ (both at the national average wage). Both families have two children (aged 2 and 3), who use childcare full-time in a typical day-care center.

Panel A in Fig. 13.5 shows the out-of-pocket costs for ECEC, separately for single parents and couples with children. These are nominal amounts, relative to the average wage in a country. This shows that, generally, the single-parent family pays less for childcare (in absolute terms) compared to the couple. This might be the case because the single-parent household (as defined above) has a lower disposable household income. In Sweden, the childcare fees are a percentage of household income. In Luxembourg, single parents receive a higher benefit/compensation for the childcare costs. Panel B shows the costs of families' childcare expressed as a percentage of their disposable household income; thus, a dual-earner family can more easily carry these costs. Indeed, here it is shown that in the majority of countries, single parents pay a larger (and sometimes substantially larger) share of their disposable household income for the same amount of childcare as couples with children. In Ireland, single parents pay more than $40 \%$ of their disposable household income, whereas in the United States, single parents pay nearly $60 \%$. 
Together, these graphs suggest that single parents tend to pay less for childcare compared to couples with children, in part because of lower childcare fees and because of higher benefits/compensation. Yet, as single parents lack a second earner in the household, these costs impose a larger burden on their disposable household income-in some countries, substantially more so.

\section{Parental Leave}

There are a number of data infrastructures on parental leave legislation and benefits. However, there are no indicators that quantify separately the social rights of single parents versus couples with children. Only in one case such indicators are currently under development.

The International Network on Leave Policies and Research presents an annual review of leave policies, and the 2019 edition (Koslowski, Blum, Dobrotić, Macht, \& Moss, 2019) covered 45 countries, including countryspecific reports and country-comparative indicators on maternity, paternity, parental leave, and other leave measures. Durations of leave, paid leave, and well-paid leave are reported, and conditions for flexibility are systematically indicated. However, it is not systematically indicated whether or not single parents have specific rights, other than in the notes of countryspecific situations. For instance, it is reported that unpaid childcare leave has an extended duration for single parents in Bulgaria, leave to care for sick children in Chile is transferable to the father in case of the mother's death, and single mothers in Finland have the right to paternity benefit days. Although this is valuable information, uncoded data do not lend themselves well for quantitative, comparative analysis. Similarly, the Mutual Information System of Social Protection ${ }^{5}$ provides qualitative descriptions of leave policies that sometimes highlights specific rights for single parents but does not systematically quantify these rights. The OECD Family Database does provide quantified indicators on leave policies, including the duration and pay levels, information on users of leave, additional leave entitlements for working parents, and replacement rates that are based on the model family types, but the information is not yet differentiated to single parents and couples with children.

The Parental Leave Benefits database, part of the SPIN infrastructure introduced above, is currently developing indicators that explicitly focus on

\footnotetext{
${ }^{5}$ https://www.missoc.org.
} 


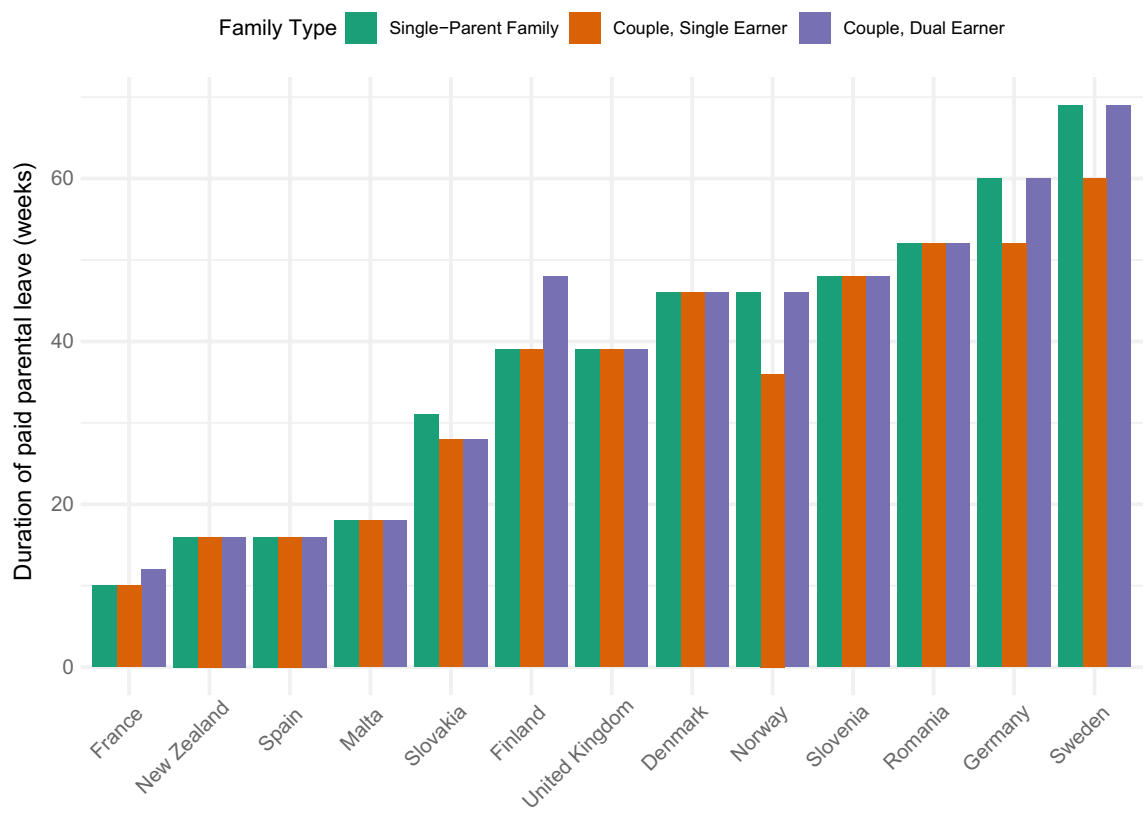

Fig. 13.6 Duration of parental leave varies more between countries than between family types (Source Parental Leave Benefits database [preliminary data])

single-parent families. ${ }^{6}$ Using model families, a number of aspects of these leave policies are coded in a way that is comparable to couples with children. This includes the duration and wage replacement rates during maternity, paternity, and childcare leave, as well as other income support benefits directly related to early parenthood. For some countries, preliminary results are presented below. It should be noted that these results should be cautiously interpreted. Nonetheless, some interesting patterns emerge.

Figure 13.6 shows the durations of paid leave in 13 countries for three model family types: a single-parent family, a single-earner couple, and a dualearner couple. The durations include wage replacement and are for maternity leave, parental leave, paternity, and/or childcare leave. Unpaid periods of leave are not included. In the single-earner couple it is the person who was employed who takes the leave, and the person who was not working does not take any leave (even if it would be available to them). The dual-earner couple is assumed to take their leave in a way that maximizes the duration of their leave, therefore benefitting from additional durations of leave awarded

\footnotetext{
${ }^{6}$ We in particular thank Sofie Burman for her hard work on making these indicators available to us, as well as Pär Dalén, and take any responsibility ourselves for the fact that these are preliminary results subject to change.
} 
when the leave is taken equally, and taking their leave sequentially (rather than together at the same time) when allowed.

The results show that by and large, each of these family types receives the same or very similar durations of leave rights in most countries, and that differences between countries vastly exceed differences between family types. In Finland and France, single parents receive shorter leave compared to the dual-earner couple, because in in these countries parental leave for fathers is not transferable to single parents. Slovakia provides three weeks of extended leave for single mothers with newborns. In a few other countries, including Norway, Germany, and Sweden, the single-earner couple actually receives shorter leaves than the single parents or dual-earner couple: in these countries the parental leave scheme is set up to encourage gender-equal taking up of parental leave, but do not penalize single parents in case they are not able to share the parental leave equally.

At first glance, the duration of parental leave does not necessarily benefit single-parent families more or less. Therefore, Fig. 13.7 takes a different approach. It does not show the duration of paid leave but the total income replacement (related to having a young child) that different families would

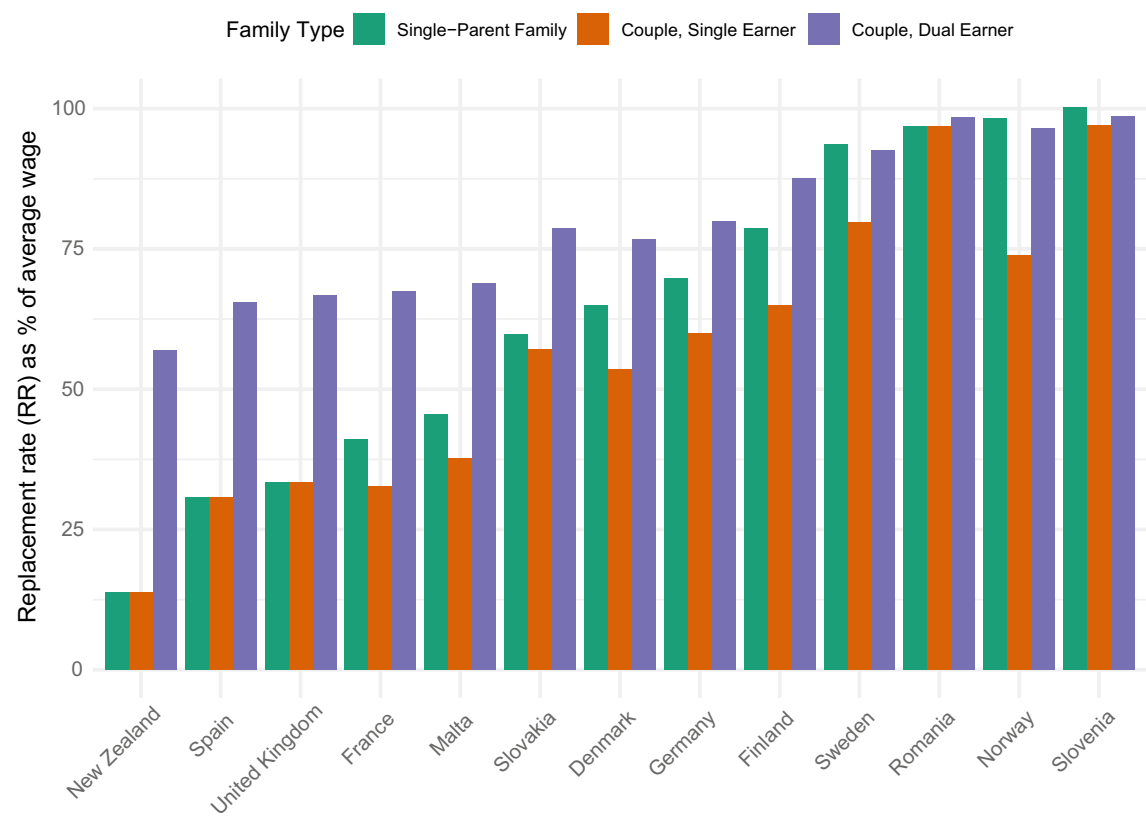

Fig. 13.7 Income replacement of full-year parental leave, single parents receive slightly more; however, leave varies more between countries than between family types (Source Parental Leave Benefits database [preliminary data]) 
receive. The replacement rate is here defined as the total household income while a parent is taking parental leave as a percentage of the income before taking leave-assuming that everything else remained the same. It is furthermore assumed that each worker has an average wage, and that the families choose to be on leave, or otherwise not on the job, for a full year-even if they are entitled to a shorter period of leave. The calculation of income replacement for a full year in each country provides a comparable indication of how flexible families can be in choosing their own duration of leave. It is calculated how much their total income differs from their average wage prior to the year on leave. In these calculations, wage replacement during parental leave is accounted for, as well as benefits related directly to early parenthood. This includes child benefits, tax credits, and to the extent that the government guarantees child support payment to the single parent if the "other parent" does not pay. For an extensive review on child support, see Chapter 12 by Skinner and Hakovirta in this volume.

The duration of parental leave captures the degree to which a family can stay home to provide full-time care for their newborn without having to rely on additional benefits such as social assistance. Similar to the out-of-work benefits shown in Fig. 13.4, the couple with children can have a second earner in the household, whereas this is typically not the case for single parents. As such, single parents would have to rely solely on these levels of income to avoid claiming other benefits such as social assistance, whereas couples with young children may have other sources of income to compensate for the income loss during parental leave. The impact of this is represented by the distinction among the orange bars (couple with children, single earner) that show the rate of wage replacement only for the person on leave. The purple bars (couple with children, dual earner) show the effective level of income a dual-earner family has when one parent goes on full-time leave for a year while the other parent remains working full-time at the average wage.

Figure 13.7 confirms the earlier results that the differences among countries seem to be more substantial than the difference between single-parent families (green bars) and single earner couples (orange bars). In most countries, single parents receive slightly more than the single-earner couple-in part resonating the finding in Fig. 13.6 that many countries incentivize gender-equal sharing of the parental leave, and in part due to the state providing guaranteed payment of child support. The United Kingdom, for instance, had a fairly average duration of parental leave matched with low levels of income replacement and targeted child benefits for low-income parents. Thus, parents with an average wage end up with a low level of income replacement if parents go on leave for the full year. 
The small differences between the green and orange bars show that most countries do not provide very different entitlements to people taking leave based on their family composition. However, in terms of household income during leave, it matters greatly whether there is a second earner in the household-something single parents often do not have access to. This is demonstrated by the purple bars, which show the effective income of a couple where one partner goes on full-time leave and the other continues full-time employment. Naturally, their income is substantially higher than that of a single earner going on leave. In countries with low replacement rates during parental leave, the income position of single parents falls substantially behind that of dual-earner couples, not because they receive a substantially lower replacement of their own wage but because they do not have a second earner in the household. In other words, although the policy provisions are fairly similar across family types, how these policies play out results in very different situations for families.

\section{Conclusion}

In societies with increasingly diverse family structures, it is important to address uniqueness of families while also providing universal family policies to all. The evidence is clear that all families with children benefit from family policies that include child income support, ECEC, and paid parental leave, and that these benefits are extended to single parents. These policies help to level the playing field for all families, and in numerous cases, it was shown that single parents actually benefit more than couples with children.

For child income support-and in particular, family benefits-the results are quite clear. The evidence is strong that family benefits do in fact lower poverty for all families and especially for single-parent families. Family benefits are more effective for single parents, not because they are closer to the poverty line but because they receive higher amounts of family benefits. In addition, because of economies of scale, even receiving the same amount as two-parent families would benefit single-parent families more. The differences among countries suggest that family benefits significantly reduce poverty for couple-parent families more so than for single-parent families. The only two exceptions, Luxembourg and Estonia whose family policies benefit those families with the most resources as opposed to families that are resource poor.

ECEC policies are perhaps the most important in facilitating mothers' employment (Olivetti \& Petrongolo, 2017). The literature review clearly 
showed how childcare provisions facilitate single parents with young children to be employed, improve work-life balance, have health benefits, and even reach into the middle class. The empirical results, however, showed that the ECEC costs in many countries represent a larger share of their household budget compared to dual-earner couples.

The literature review further indicated that paid parental leave-if not overly long — can be beneficial to all families with children. Although there is some evidence that parental leave benefits single parents slightly more, the mechanism does not seem to be based on single parents receiving longer periods of leave or substantially higher wage replacements. Parental leave entitlements clearly differed more among countries than among family types. Thus, the findings in the literature that single parents still benefit more from parental leave than people in two-parent households might not be due to differentiated leave entitlements but rather to the absence of a second earner and care giver in the household. Yet, the empirical results suggested that particularly in countries with low replacement rates during parental leave, the income position of single parents on leave is substantially worse than among dual-earner parents.

It is highly conventional to conclude a chapter like this by calling for better family policy indicators to facilitate future research. We leave most of that work to the chapters in the final section of this Handbook-in particular, Chapter 24 by Sirén, Doctrinal, Nieuwenhuis, and Van Lancker in this volume. There is, however, one important finding that requires more attention here. In both the data on ECEC and on parental leave, we found that although the provisions to single parents and couples with children were highly similar, single parents were comparatively worse off. In dual-earner societies, single parents find it challenging to pay even a slightly reduced childcare fee or be on a single-wage replacement during leave. Paradoxically, we also found support in the literature that despite the discrepancies between their entitlements regarding ECEC and leave policies, single parents use these policies to the same extent as couples (e.g., Van Lancker, 2018), and in some cases, to greater effects in terms of employment and poverty reduction. To resolve this paradox requires more family policy indicators that examine in detail the entitlements provided to different family types.

However, this finding not only represents a challenge in data collection but also a true challenge to policy makers, related to selectivity within universalism (cf. Van Lancker \& Van Mechelen, 2015). If equal provisions of the policy produce unequal living conditions, this raises questions of horizontal and vertical equity, as well as the distinction between the equality of policy provision and the equality of policy outcomes. Addressing these challenges 
is ever more pertinent in societies where large shares of dual-earner couples influence what are commonly accepted living standards. In such societies, the challenge is to design equitable family policies with provisions to single parents that are adequate in relation to the provisions and other income sources of couples with children.

This review of the literature and analysis of selected data infrastructures has demonstrated that family policies are indispensable for single parents and their families. Even when the policy provisions do not seem specifically tailored to single parents, they benefit. Even when single parents have to pay a larger share of their household income to ECEC services, it seems they still benefit from the provided care. In a time that family forms have become more diverse, and family relations change more over time and within one's life-course, it is an important lesson that the family policies envisioned byand the principles underlying - the dual earner, dual carer model also benefit the single earner, single carer, single parent.

Acknowledgements Nieuwenhuis was financially supported by FORTE: the Swedish Research Council for Health, Working Life and Welfare (grant number 2018-00988).

\section{References}

Alm, S., Nelson, K., \& Nieuwenhuis, R. (2020). The diminishing power of one? Welfare state retrenchment and rising poverty of single-adult households in Sweden 1988-2011. European Sociological Review, 36 (2), 198-217.

Bainbridge, J., Meyers, M. K., \& Waldfogel, J. (2003). Child care policy reform and the employment of single mothers. Social Science Quarterly, 84(4), 771-791.

Baude, A., Pearson, J., \& Drapeau, S. (2016). Child adjustment in joint physical custody versus sole custody: A meta-analytic review. Journal of Divorce \& Remarriage, 57(5), 338-360. https://doi.org/10.1080/10502556.2016.1185203.

Berger, M. C., \& Black, D. A. (1992). Child care subsidies, quality of care, and the labor supply of low-income, single mothers. The Review of Economics and Statistics, $74(4), 635$.

Bernardi, L., \& Mortelmans, D. (Eds.). (2018). Lone parenthood in the life course. Cham, Switzerland: Springer.

Bonoli, G. (2013). The origins of active social policy: Labour market and childcare policies in a comparative perspective. Oxford, UK: Oxford University Press.

Bradshaw, J., Ditch, J., Holmes, H., \& Whiteford, P. (1993). Support for children: A comparison of arrangements in fifteen countries. London: HMSO. 
Bradshaw, J., \& Finch, N. (2002). A comparison of child benefit packages in 22 countries (Research Report No. 174). London: Department for Work and Pensions.

Bradshaw, J., Keung, A., \& Czhen, Y. (2018). Cash benefits and poverty in singleparent families. In R. Nieuwenhuis \& L. C. Maldonado (Eds.), The triple bind of single-parent families: Resources, employment and policies to improve wellbeing (pp. 337-358). Bristol, UK: Policy Press.

Brady, D., \& Burroway, R. (2012). Targeting, universalism, and single mother poverty: A multilevel analysis of 18 affluent democracies. Demography, 49, 719-746.

Brady, D., Finnigan, R. M., \& Hübgen, S. (2017). Rethinking the risks of poverty: A framework for analyzing prevalences and penalties. American Journal of Sociology, 123(3), 740-786.

Byun, Y.-H. (2018). Middle-class single parents. In R. Nieuwenhuis \& L. C. Maldonado (Eds.), The triple bind of single-parent families: Resources, employment and policies to improve wellbeing (pp. 223-338). Bristol, UK: Policy Press.

Chzhen, Y., \& Bradshaw, J. (2012). Lone parents, poverty and policy in the European Union. Journal of European Social Policy, 22(5), 487-506. https://doi.org/ $10.1177 / 0958928712456578$.

CSB Minimum Income Protection Indicators (MIPI) Database. (2020). Retrieved from http://www.centrumvoorsociaalbeleid.be/index.php?q=node/3270.

Doctrinal, L., Nelson, K., \& Sirén, S. (2015). Comprehensive indicators for the analysis of out-of-work benefits: Introducing the out-of-work benefits dataset (InGRID Deliverable 22.3). Stockholm: Swedish Institute for Social Research.

Duvander, A.-Z., \& Jans, A.-C. (2009). Consequences of fathers parental leave use: Evidence from Sweden. Finnish Yearbook of Population Research, 44, 49-62.

Duvander, A.-Z., \& Korsell, N. (2018). Whose days are left? Separated parents' use of parental leave in Sweden. In R. Nieuwenhuis \& L. C. Maldonado (Eds.), The triple bind of single-parent families: Resources, employment and policies to improve wellbeing (pp. 263-284). Bristol, UK: Policy Press.

Esser, I., \& Olsen, K. M. (2018). Matched on job qualities? Single and coupled parents in European comparison. In R. Nieuwenhuis \& L. C. Maldonado (Eds.), The triple bind of single-parent families: Resources, employment and policies to improve wellbeing (pp. 285-310). Bristol, UK: Policy Press.

EUROMOD Hypothetical Household Tool (HHot). (2020). Retrieved from https:/www.euromod.ac.uk/using-euromod/user-resources/hhot-manual-househ olds.

Evertsson, M., \& Nermo, M. (2007). Changing resources and the division of housework: A longitudinal study of Swedish couples. European Sociological Review, 23(4), 455-470. https://doi.org/10.1093/esr/jcm018.

Ferrarini, T., Nelson, K., Korpi, W., \& Palme, J. (2013). Social citizenship rights and social insurance replacement rate validity: Pitfalls and possibilities. Journal of European Public Policy, 20(9), 1251-1266. https://doi.org/10.1080/13501763. 2013.822907. 
Fransson, E., Brolin Lafman, S., Ostberg, V., Bergstrom, M., \& Olsen, K. M. (2018). Wellbeing among children with single parents in Sweden: Focusing on shared residence. In R. Nieuwenhuis \& L. C. Maldonado (Eds.), The triple bind of single-parent families: Resources, employment and policies to improve wellbeing (pp. 145-170). Bristol, UK: Policy Press.

Gambaro, L., Stewart, K., \& Waldfogel, J. (2015). An equal start? Providing quality early education and care for disadvantaged children. Bristol, UK: Policy Press.

Gornick, J. C., \& Jäntti, M. (2012). Child poverty in cross-national perspective: Lessons from the Luxembourg income study. Children and Youth Services Review, 34(3), 558-568.

Gornick, J. C., \& Meyers, M. (2003). Families that work: Policies for reconciling parenthood and employment. New York: Russell Sage Foundation.

Gornick, J. C., \& Smeeding, T. M. (2018). Redistributional policy in rich countries: Institutions and impacts in nonelderly households. Annual Review of Sociology, 44(1), 441-468. https://doi.org/10.1146/annurev-soc-073117-041114.

Härkönen, J. (2018). Single-mother poverty: How much do educational differences in single motherhood matter? In R. Nieuwenhuis \& L. C. Maldonado (Eds.), The triple bind of single-parent families: Resources, employment and policies to improve well-being (pp. 31-50). Bristol, UK: Policy Press.

International Network of Leave Policies and Research. (2020). Retrieved from http://www.leavenetwork.org.

Kenworthy, L. (2011). Progress for the poor. New York: Oxford University Press.

Korpi, W., \& Palme, J. (1998). The paradox of redistribution and strategies of equality: Welfare state institutions, inequality, and poverty in the western countries. American Sociological Review, 63(5), 661-687.

Koslowski, A., Blum, S., Dobrotić, I., Macht, A., \& Moss, P. (2019). International review of leave policies and research 2019. Available at: https://www.leavenetwork. org/annual-review-reports/.

Luxembourg Income Study (LIS) Database. (2020). Retrieved from https://www.lis datacenter.org. Luxembourg: LIS.

Maldonado, L. C., \& Nieuwenhuis, R. (2015). Family policies and single parent poverty in 18 OECD countries, 1978-2008. Community, Work \& Family, 18(4), 395-415.

Marchal, S., \& Van Lancker, W. (2019). The measurement of targeting design in complex welfare states: A proposal and empirical applications. Social Indicators Research, 143(2), 693-726. https://doi.org/10.1007/s11205-018-1995-z.

Marshall, T. H. (1950). Citizenship and social class. Cambridge, UK: Cambridge University Press.

Marx, I., Salanauskaite, L., \& Verbist, G. (2016). For the poor, but not only the poor: On optimal pro-poorness in redistributive policies. Social Forces, 95(1), $1-24$.

McLanahan, S. (2004). Diverging destinies: How children are faring under the second demographic transition. Demography, 41(4), 607-627. 
Millar, J., \& Rowlingson, K. (Eds.). (2001). Lone parents, employment and social policy: Cross-national comparisons. Bristol, UK: Policy Press.

Misra, J., Moller, S., \& Budig, M. (2007). Work-family policies and poverty for partnered and single women in Europe and North America. Gender \& Society, 21(6), 804-827.

Moilanen, S., May, V., \& Räikkönen, E. (2016). Mothers' non-standard working and childcare-related challenges: A comparison between lone and coupled mothers. International Journal of Sociology and Social Policy, 36(1/2), 36-52.

Morissens, A. (2018). The role of universal and targeted family benefits in reducing poverty in single-parent families in different employment situations. In R. Nieuwenhuis \& L. C. Maldonado (Eds.), The triple bind of single-parent families: Resources, employment and policies to improve wellbeing (pp. 359-382). Bristol, UK: Policy Press.

Nelson, K. (2004). Mechanisms of poverty alleviation: Anti-poverty effects of nonmeans-tested and means-tested benefits in five welfare states. Journal of European Social Policy, 14(4), 371-390. https://doi.org/10.1177/0958928704046879.

Nepomnyaschy, L., \& Waldfogel, J. (2007). Paternity leave and fathers' involvement with their young children. Community, Work, \& Family, 10(4), 427-453.

Nielsen, L. (2014). Shared physical custody: Summary of 40 studies on outcomes for children. Journal of Divorce \& Remarriage, 55(8), 613-635. https://doi.org/ 10.1080/10502556.2014.965578.

Nieuwenhuis, R. (2020). Directions of thought for single parents in the EU. Community, Work \& Family. https://doi.org/10.1080/13668803.2020.1745756.

Nieuwenhuis, R., \& Maldonado, L. C. (2018a). Single parent families and in-work poverty. In H. Lohmann \& I. Marx (Eds.), Handbook of research on in-work poverty (pp. 171-192). Cheltenham, UK: Edward Elgar.

Nieuwenhuis, R., \& Maldonado, L. C. (Eds.). (2018b). The triple bind of singleparent families: Resources, employment and policies to improve wellbeing. Bristol, UK: Policy Press.

Nieuwenhuis, R., Need, A., \& Van der Kolk, H. (2017). Is there such a thing as too long childcare leave? International Journal of Sociology and Social Policy, 37(1/2), 2-15. https://doi.org/10.1108/IJSSP-07-2015-0074.

Nieuwenhuis, R., Tøge, A., \& Palme, J. (2018). The health penalty of single parents in institutional context. In R. Nieuwenhuis \& L. C. Maldonado (Eds.), The triple bind of single-parent families: Resources, employment and policies to improve wellbeing (pp. 311-336). Bristol, UK: Policy Press.

OECD Family Database. (2020). Retrieved from http://www.oecd.org/social/fam ily/database.htm.

Olivetti, C., \& Petrongolo, B. (2017). The economic consequences of family policies: Lessons from a century of legislation in high-income countries. Journal of Economic Perspectives, 31(1), 205-230. https://doi.org/10.1257/jep.31.1.205.

Pettit, B., \& Hook, J. L. (2009). Gendered tradeoffs: Family, social policy, and economic inequality in twenty-one countries. New York: Russell Sage Foundation. 
Rowlingson, K., \& McKay, S. (2002). Lone parent families: Gender, class and state. London: Routledge.

Skocpol, T. (1991). Targeting within universalism: Politically viable policies to combat poverty in the US. In C. Jencks \& P. Peterson (Eds.), The urban underclass (pp. 411-436). Washington, DC: The Brookings Institution.

Social Policy Indicator (SPIN) Database, Out of Work Benefits Database, \& Parental Leave Benefits Database. (2020). Retrieved from http://www.spin.su.se. Sutherland, H., \& Figari, F. (2013). EUROMOD: The European Union tax-benefit microsimulation model. International Journal of Microsimulation, 6(1), 4-26.

UN Women. (2019, March). Progress of the world's women. Retrieved from https:// www.unwomen.org/en/digital-library/progress-of-the-worlds-women.

Van Lancker, W. (2018). Does the use of reconciliation policies enable single mothers to work? A comparative examination of European countries. In R. Nieuwenhuis \& L. C. Maldonado (Eds.), The triple bind of single-parent families: Resources, employment and policies to improve wellbeing (pp. 239-262). Bristol, UK: Policy Press.

Van Lancker, W., Ghysels, J., \& Cantillon, B. (2015). The impact of child benefits on single mother poverty: Exploring the role of targeting in 15 European countries. International Journal of Social Welfare, 24(3), 210-222.

Van Lancker, W., \& Horemans, J. (2017). Childcare policies and in-work poverty. In H. Lohmann \& I. Marx (Eds.), Handbook of research on in-work poverty (pp. 261-276). Cheltenham, UK: Edward Elgar.

Van Lancker, W., \& Van Mechelen, N. (2015). Universalism under siege? Exploring the association between targeting, child benefits and child poverty across 26 countries. Social Science Research, 5, 60-75.

Van Mechelen, N., Marchal, S., Goedemé, T., Marx, I., \& Cantillon, B. (2011). The CSB-Minimum Income Protection Indicators dataset (CSB-MIPI) (WP 11/05). Antwerp: University of Antwerp.

Van Oorschot, W., \& Roosma, F. (2017). The social legitimacy of targeted welfare and welfare deservingness. In W. Van Oorschot, B. Meuleman, F. Roosma, \& T. Reeskens (Eds.), The social legitimacy of targeted welfare: Attitudes to welfare deservingness (pp. 3-33). Cheltenham: Edward Elgar.

Zagel, H. (2014). Are all single mothers the same? Evidence from British and West German women's employment trajectories. European Sociological Review, 30(1), 49-63. 
Open Access This chapter is licensed under the terms of the Creative Commons Attribution 4.0 International License (http://creativecommons.org/licenses/by/4.0/), which permits use, sharing, adaptation, distribution and reproduction in any medium or format, as long as you give appropriate credit to the original author(s) and the source, provide a link to the Creative Commons licence and indicate if changes were made.

The images or other third party material in this chapter are included in the chapter's Creative Commons licence, unless indicated otherwise in a credit line to the material. If material is not included in the chapter's Creative Commons licence and your intended use is not permitted by statutory regulation or exceeds the permitted use, you will need to obtain permission directly from the copyright holder. 